\title{
Translating Anthropomorphic Metaphors: An Ecostylistic Contrastive Analysis of Grazia Deledda's The Mother
}

\author{
Eleonora Fois ${ }^{1}$ \\ ${ }^{1}$ University of Cagliari, Italy \\ Correspondence: Eleonora Fois, University of Cagliari, Italy. E-mail: eleonora.fois@unica.it
}

Received: July 22, $2021 \quad$ Accepted: October 21, $2021 \quad$ Online Published: November 5, 2021

doi:10.5539/ijel.v12n1p1 URL: https://doi.org/10.5539/ijel.v12n1p1

\begin{abstract}
This contribution explores the translation of anthropomorphic metaphors via a contrastive analysis of La madre, by the Sardinian Nobel Laureate in Literature Grazia Deledda, and its 1922 translation (The Mother) by Mary Steegman.

It will be argued that the target readers' perception of the symbolic relationship between landscape and cultural identity, which Deledda presents metaphorically through the use of anthropomorphism, can be reshaped by the translator's interpretation. To explore the patterns that reveal the translator's approach to anthropomorphic metaphors, the study will be based on Conceptual Metaphor Theory (CMT), notably Prandi's distinction and theory on metaphor translation (2019), and ecostylistics.
\end{abstract}

Keywords: anthropomorphism, metaphors, literary translation, ecostylistics

\section{Landscape and Metaphors}

Landscape can be defined as the natural environment in which the narrative characters operate. Landscape is a representation of nature as seen by humans, usually in terms of separation and dualism (Steinhagen, 1999, p. 64). Particularly, the idea of landscape was affected by the Cartesian dualism and its premise of the primacy of the human intellect: even nature is molded according to humans' values, needs, hopes (Steinhagen, 1999, p. 65). Landscape is thus a cultural construction:

Even the most humble, innocuous-looking landscape carries with it cultural meaning, sometimes clearly visible but often in a sort of code that is absorbed by local inhabitants at a subconscious level. This is why exotic areas, outside our normal, everyday experience are difficult for us to understand and appreciate, and sometimes even unsettling and threatening (Atkins, 1998, p. 1, emphasis added).

As Gavins and Lahey pointed out, language is a world-building process, at the core of which are the cultural and social roots of language, actualized in personal knowledge and experience $(2016$, p. 3). As a result, the lack of shared experience makes expressing ideas about a foreign landscape difficult. However, 'landscape is an object that is produced and framed - that is, focalised - and hence intrinsic to the narrative structure' (Eggan, 2018, p. 401), in that it creates the ideological framing of the narration. Translating space is thus one further challenge for translators, who must transfer not just words but also spaces. As De Bleeker says, little is known about the impact of the translator's choices on the way a reader imagines and interprets narrative space (2014, p. 227). For this reason, the choices of the translator as the first reader of the Source Text (henceforth: ST) and the creator of the Target Text (henceforth: TT) represent the first step towards understanding the shifts in translating foreign landscape.

Our relationship with landscape is mediated by our capacity for metaphor (Unwin, 2019). Metaphors are often employed in literature to bridge contrasting visions: when used well, metaphors call attention to a previously ignored quality or present a fresh and fitting comparison (Muelder Eaton, 1990, p. 25). In landscape descriptions, for instance, metaphors facilitate the expression of meanings by applying old and familiar labels in new ways (Goodman, 1968). More specifically, anthropomorphism is a means to establishing a relationship between human beings and nature. Anthropomorphism reduces the distance and the difference between humans and the rest of the world by projecting a human identity onto something nonhuman (Danta, 2013, p. 71): humanizing the environment is a way to control its "primeval [sic] unknownness and terror" (Porteous, 1986, p. 10). On the other hand, the anthropomorphic vision of nature is shaped by culture, as people filter the others and the natural 
world through the prism of culturally determined principles or ideologies (Epley Waytz, \& Cacioppo, 2007, p. 867). Thus, the translator's intercultural sensitivity is pivotal in re-building the cultural vision of the landscape, and thus in understanding when such a vision is conveyed also by anthropomorphic metaphors.

Assuming that anthropomorphism is the textual embodiment of the symbolic relationship between landscape and cultural identity (Lahey, 2010, p. 156), this contribution investigates the way anthropomorphic metaphor was modified from the ST to the TT via a contrastive analysis of Sardinian Nobel Laureate in Literature Grazia Deledda's novel and its 1922 translation (The Mother) by Mary Steegman. La Madre was Deledda's third translated novel but her internationally best-known work (Migiel, 1994, p. 114).

While there is no framework concerning the history of translation to be used as a reference, previous analyses on the translation of La Madre into English (Fois, 2020a, 2020b, 2020c) demonstrated the impact of Steegman's domesticating approach and ideological perspective on her rendition of foreign landscape in her translation. The most revealing translating choices involve the treatment of numerous specific botanical terms Deledda used to describe Sardinia in geographically concrete terms, which were either neutralized or substituted: the reference to the "Linterno" (Deledda, 1920, p. 131), a Mediterranean plant commonly known as buckthorn, is omitted altogether, despite a direct translation being available; the Levant wind (Deledda, 1920, p. 68), typical of the Mediterranean region, becomes "wind from the eastern hills" (Deledda, 1923, p. 69); on the other hand, the general noun "alberelli" (small trees. Deledda, 1920, p. 68) becomes "aspens" (Deledda, 1923, p. 49), which are tall and narrow. At the same time, the natural elements are emphasized to enhance mystery or ambiguity: e.g., the premodifier "vivo" (alive. Deledda, 1920, p. 43) referring to the wind is translated with "ghostly" (Deledda, 1923, p. 43; Fois, 2020a), conforming to the image of a wild and mysterious landscape traditionally conveyed by eighteenth-century travel literature (Fois, 2014). Furthermore, Steegman chose to avoid direct translation of metaphor, opting either for a translation with sense or a shift from metaphor to simile (Fois, 2020c). Since translating a metaphor with a simile privileges the translator's interpretation rather than the conflictual complex meaning (Prandi, 2019, p. 99), Deledda's conceptual and stylistic framework was certainly modified.

Given these premises, the present contribution will examine anthropomorphic metaphors in greater detail. Since "metaphor is not so easy to identify without an attentive 'traditional' reading of the text" (Johnson, 2009, p. 16), a qualitative contrastive analysis is still needed to assess the relationship between metaphor and landscape in Deledda's writing, which is the purpose of this contribution. The methodological framework for the contrastive analysis will draw on Conceptual Metaphor Theory (CMT; Lakoff, 1986; Lakoff \& Johnson, 2003), so as to define the cultural influence which shapes the way reality is perceived and guide the translator's choices. The specific reference in analyzing anthropomorphic metaphors will be Prandi's distinction between Conventional and Living metaphors (2019) and the related translation theory $(2017,2019)$. The methodogical framework also includes ecostylistics, which, starting from the awareness of the way languages foreground the environment (Fill \& Muhlhauser, 2001, p. 3), explores the textual representation of the physical environment from a stylistic perspective (Douthwaite et al., 2017, p. 2). Applied to translation only recently (Zerkowitz, 2017), ecostylistics will be used to analyze the patterns revealing the translator's approach with regards to nature and landscape.

Section 2 will introduce the features and cultural significance of anthropomorphic metaphors; Section 3 will focus on the translational problems concerning anthropomorphic metaphors; Section 4 will present Grazia Deledda and the novel La Madre; finally, Section 5 will carry out the contrastive analysis of source and target text.

\section{Anthropomorphism and Anthropomorphic Metaphors}

Anthropomorphism is defined as the attribution of 'unobservable features' (Epley et al., 2007, p. 865) and human mental and affective states to non-human entities (Airenti, 2019, p. 8). Acknowledged as a key element in religion (Westh, 2009), anthropomorphism is a universal phenomenon whose antecedent is sociality motivation. Humans have a natural urge to form and sustain social ties, which is why anthropomorphism is employed in children's books to help readers empathize with the characters (Markowsky, 1975). However, far from being a merely childish approach to the surrounding environment, anthropomorphism is a "specific human attitude" sharedy by both children and adults (Airenti, 2019, p. 13). Being able to experience emotions, the anthropomorphised element is worthy of moral concern (Gray \& Wegner, 2009). Therefore, from a poetic and linguistic perspective, anthropomorphism "emerges not "just" as a rhetorical trope, but as a linguistic move with deep philosophical implications' (Regier, 2006, p. 412). In the postindustrial age, dominated by ideas of industrialization and capitalization, anthropomorphism is instead perceived as a sign of naivety and short-sightedness (Grech, 2018, pp. 33-34). Therefore, one of the elements indicating the anthropocentric approach to the landscape is the negative perception of anthropomorphism mirrored by anthropocentric 
languages foregrounding the distance between humans and the rest of creation (Fill \& Muhlhauser, 2001, p. 5) and predisposing readers to a definite perception of actions.

Anthropomorphism is grounded in perception and individual variability. Perception implies that the anthropomorphizing action involves not the entity (in this article, the elements of the landscape) but rather the relationship that a person establishes with said entity (Airenti, 2019, p. 9). Individual variability implies and derives from an affective state rather than the knowledge of the anthropomorphized object. This theoretical point has important repercussions on translation. When the anthropomorphized entity is a landscape element, the translator should technically be able to render the anthropomorphic metaphor despite the different spatial references, provided that the emotive function of anthropomorphic metaphors is acknowledged.

According to Conceptual Metaphor Theory (CMT), metaphor is "primarily a matter of thought and action" (Goatly, 1997, p. 153) expressed linguistically. Metaphors "are constructed on the field as contingent textual interpretations that challenge basic conceptual structures and relations" (Prandi, 2017, electronic version), and their interpretation and linguistic form depend on shared concepts and conceptual structures (Lakoff \& Johnson, 1980). Within this framework, there can exist "conventional" and "living" metaphors (Prandi, 2017). Conventional metaphors belong to a shared repertoire: they are consistent, coherent, and not conflictual. On the contrary, living metaphors are incoherent, non-conventional and creative (Prandi, 2015, p. 84), their foundation being a conflictual relation between its constituents. Living metaphors are conflictual in defining abstract and physical entities and are supported by an entire syntactic unit which engages in a willingly creative concept (Prandi, 2019, p. 29). Therefore, they require interpretation. Different visions on coherence and conventionality can lead to variation in experiential focus - the different embodiment for the metaphorical conceptualization - and salience - the different importance placed by speakers on aspects which become domains of metaphor (Kövecses, 2014).

From a cognitive metaphor perspective, anthropomorphism implies the LANDSCAPE IS A PERSON/CHARACTER mapping (Lahey, 2010, p. 162). Anthropomorphic metaphors belong to the living metaphor category (Prandi, 2010, 2015, 2017, 2019), which build conceptual conflict by attributing human states to non-human elements while their meaning (that is, the attribution of human features to non-human entities) remains unambiguous (Prandi, 2015, p. 88). A living metaphor with a clear anthropomorphic imprint challenges the addressee's (thus, the translator's) ontological presuppositions (Prandi, 2019, p. 27). Anthropomorphic metaphors, as all conflictual metaphors, are open to interpretation, hence their reproduction in the TT is reliant on the translator's cultural framework and translation strategy. Firstly, anthropomorphism entails subjective assessment of similarity (Williams et al., 2021). Secondly, the need to access a culturally salient understanding of the notion underlying a metaphor, without which the transfer cannot take place, confirms the intrinsically cultural nature of anthropomorphism (Dancygier \& Sweetser, 2014, p. 141).

Therefore, the translation of anthropomorphic metaphors depends on whether the translator acknowledges their function and meaning in the text and deems them acceptable for the target culture, which in turn depends on the anthropocentric vision embedded in the translator's mind. Thus, the outcome of anthropomorphic metaphor in translation might bring to light the inherently anthropocentric and often androcentric underpinnings of environmental discourses or help to ascertain the (more or less conscious) connection between nature and human beings.

There is little doubt as to the strength of such a connection in Grazia Deledda's works. Corpus-based analyses on her novels (Johnson, 2009) showed that the landscape mirrors the character's mood and feelings: in fact, lexical words concerning natural landscape (i.e., 'cielo - sky', 'vento - wind', and 'mare - sea') frequently occur with verbs indicating mental processes ('parere' and 'sembrare' - seem), in turn related to the character's feelings and thoughts. Tipi e Paesaggi Sardi (Sardinian characters and landscapes, 1901), an essay published soon after Deledda's move to Rome, shows her sensitivity to the Sardinian landscape in non-narrative works. Anecdotes on some folkloristic and historical characters are interspersed with accurate landscape descriptions where metaphors abound ('the Candia sails quick and white like a white swan'; 'the clouds are immense eagles with their wings tucked', Deledda, 1901, p. 38, translation mine) and anthropomorphism is equally relevant (the rocks of the coast guard the lonely sea, Deledda, 1901, p. 38, translation mine). Since anthropomorphism defines natural items as agents worthy of respect (Fois, 2020a, 2020b, 2020c; Epley et al., 2007, p. 870), its presence is fundamental to the understanding of Deledda's vision and perception of the Sardinian landscape as an active character.

\section{Translating Metaphors}

In cognitive terms, metaphor translatability is determined by the underlying conceptualization of the metaphorical expression as a component of the systems of both source and target culture. Translating a metaphor 
requires the ability to draw a mental representation of the real world, followed by a cognitive process in which the use of language is moulded by a specific cultural dimension. As cultural beliefs and values are agents which shape the way speakers (and translators) see the world, metaphor translation unravels the culturally structured and heterogeneous nature of experience. The greater the cognitive domain mismatch between the source and target metaphor, the more challenging it will be to translate the metaphor (Mandelblit, 1995).

However, when metaphors that draw on the same domain and are rhetorically functional, such as similes or analogies, but also anthropomorphism and the pathetic fallacy, are used consistently, translation is required. (Steen, 2014, p. 18; Newmark, 1981, p. 85; Semino \& Steen, 2008, p. 240). Equally important are the interactional processes characterizing the use of these creative metaphors. Interactions can be horizontal - within a single metaphor - and vertical — connecting isolated metaphors (Grabe, 1984, p. 436). The latter unites all individual metaphors and underlies their coherence (Rezanova \& Shilyaev, 2015, p. 31) and is called megametaphor. Megametaphor is the "overarching sub-text" (Lahey, 2010, p. 159) which defines "prototypical and primitive [cultural] frames" (Werth, 1999, p. 323), i.e., the elements which guide and help build a sense of 'cultural distinctiveness' in the text (Lahey, 2010, p. 167). Failing to detect the specific vertical relationship linking all metaphors may negatively affect the cohesiveness of their translation and therefore the metaphorical impact of the TT.

Metaphor translation has been analyzed from a descriptive (Van der Broeck, 1981) and a prescriptive (Newmark, 1981) point of view, both of which are based on the interpretation of metaphor as perceived similarities between objects. Van der Broeck's tentative scheme of modes of metaphor translation includes (Van der Broeck, 1981, p. 77): (1) Translation 'sensu stricto', in which both tenor and vehicle of the source metaphor are transferred into the target language. The presence of corresponding vehicles in source and target language will give rise to an idiomatic metaphor translation. The use of different vehicles by source and target language will give rise to an anomalous or unique metaphor. This retentive mode of translating is responsible for the deviant (or 'alienating', i.e., exotic and/or archaic) character of translated metaphors. (2) Substitution, in which the vehicle is replaced and the tenor moderately corresponds. It is still an equivalent translation, for the ST and the TT share the same tenor. (3) Paraphrase, where a non-metaphorical expression is used in the target language (Van der Broeck, 1981, p. 85).

Newmark (1981, pp. 87-91) proposes seven translation procedures for stock metaphors, arranged in order of preference: 1) Replicating the same image in the target language; 2) Replacing the source language image with a standard image which does not clash with the target culture. 3) Using a simile to translate a metaphor while still retaining the image. According to Newmark, this procedure can alter the metaphor's shock value; 4) Using a compromise solution which makes the sense of the metaphor explicit. This allows to avoid comprehension issues but results in a loss of the intended effect.

Because comparability in the distribution of metaphor domains is higher in historically and culturally close languages (Steen, 2014, p. 12), a word-for-word translation may be the best solution for preserving conflictual meaning (Prandi, 2019, p. 34). As metaphorical patterns are not only a part of a writer's individual style but also a reflection of their worldview (Semino \& Steen, 2008, p. 239), the preservation of metaphor is highly dependent on cultural frameworks as well as on the translator's subjectivity, style, and preference. The individual variation introduced by the translator, as the first reader and as the recreator of the TT, might prove indispensable to explain translation shifts in text belonging to cultures that still share conceptual domains. If metaphors are substituted, paraphrased, or not translated altogether, the TT will lack the semantic density of the ST and the depiction of the characters or the setting might be weakened, which in turn affects the reception of the text (Kruger, 1991, p. 296). Verifying which different micro-level linguistic realizations are employed to express the metaphor's macro-level becomes pivotal. Manipulation which emerges from a contrastive analysis does not necessarily imply a translation error (Schäffner, 2004, p. 1267), but rather provides useful insights in terms of cultural perspectives and translator's subjectivity.

\section{The Author and the Novel}

Grazia Deledda was an incredibly prolific author. Since her debut in 1888, she published more than forty novels and numerous short stories. She was Italy's first and only woman to receive the Nobel Prize in Literature (the second woman worldwide after the Swedish writer Selma Lagerlöf). This victory allowed this self-educated woman, who had to contend with private reprobation of her career as well as a conservative critical establishment, to obtain the final consecration.

Deledda's international literary renown is inextricably linked to her Sardinian roots (her "Sardinianness". De Giovanni, 2017, p. 8). In fact, space and landscape are pointed out as major influences on Deledda's authorial 
personality (Miccinesi, 1975, p. 9; Fuller, 2000; Magistro, 2007). However, Deledda's relationship with her native island was conflictual: on the one hand, her goal was "to create a completely and exclusively Sardinian literature all by [her]self" (Deledda, 1938, p. 236, translation mine). On the other hand, the Sardinian space that she elected as one of her works' protagonists physically limited her literary ambitions: "I will never rise above our Sardinian mountains" (Deledda, 1938, p. 236).

La Madre confirms that Deledda's writing was inspired by existing, recognizable places, filtered through Deledda's subjective perception, and revealed by accurate landscape descriptions (Bitti et al., 1974, p. 196; Ruschioni, 1974, p. 445; Massaiu, 1976, p. 133). At the core of the novel is the mother, Maria Maddalena (the only character whose name was not domesticated in the English translation) who devoted her whole life to raising and educating her son, Paul. Following her mother's ambition, Paul became the priest of the small village of Aar, but fell for a woman, Agnese, who threatened to expose him when he tried to end the affair, urged by his mother. Critics lingered on the allegories concerning the impossible reconciliation between society and power, instincts and civilization, love and duty, destiny and superstition (Corrias, 2011), and the value and the meaning of sacrifice (Guarnieri, 2008), but the role of the landscape was not explored.

Three English editions (Note 1) of The Mother have been published so far. The first edition (1922) was entitled The Woman and the Priest (an evident strategy to appeal to the readers, shifting the focus on a more enticing premise). The title was changed into The Mother in the second edition, which was published in 1928, following Deledda's Nobel Prize, and included a foreword by D. H. Lawrence, whose work Sea and Sardinia (1921) was inspired by his travels to the island. Steegman's Preface and Lawrence's Foreword depict Sardinia as an exotic, 'barbaric' setting ('the mystery of an unevolved people [...] fierce, savage, barbaric'. Lawrence, 2005, pp. 103-104), employing motifs found in eighteenth-century travel accounts of the island. Today, despite the fact that many representations of Sardinia by Sardinian authors have shifted to plurality and (post-) modernity, stories confirming the "traditional image of intrinsic diversity, separateness, and archaism" (Sulis, 2017, p. 78) continue to achieve higher national and international visibility.

The third edition of The Mother was published in 1987, sparking the English rediscovery of Grazia Deledda (Cosima by Martha King will be published a year later). In 1988, Della Terza advocated a thorough analysis of Deledda's novels in translation in order to collect reliable data for a clear understanding of Deledda's international reception. Given the scarce bibliographic material on the subject, his request has apparently fallen on deaf ears. Della Terza was particularly concerned about the tendency to extend the source material through heavy reinterpretation, which he examined in the French translation of Elias Portolu.

As to the translator of La Madre, Mary G. Steegman's first documented translations date back to 1908 (Tales from Sacchetti, from the 1724 collection Il Trecentonovelle; Women of Florence, or La donna fiorentina del buon tempo antico by Isidoro Del Lungo, 1906). She translated The Book of Divine Consolation of the Blessed Angela of Foligno in 1909. There was no additional information available to explain the nearly twenty-year gap leading up to The Mother, which appeared to be her final work.

\section{Analysis}

Once the precise narratological function performed by metaphors in La Madre is acknowledged, the translation of the novel presents not only a linguistic challenge but, most importantly, a cultural challenge. The contrastive analysis will specifically target the translation of anthropomorphic metaphors and their impact on the global identity of the TT.

(1)

ST [...] poi Paulo si trovò solo, tra la fiammella tremula del lume e la luna che guardava dal finestrino [...] (Deledda, 1920, p. 147).

TT [...] and Paul found himself alone, between the flickering flame of the oil lamp and the calm splendour of the moon that shone in through the high window [...] (Deledda, 1923, p. 149).

The underlying conceptual framework in the ST is that the moon behaves like a human being and 'looks through the window', whereas the verb chosen in the TT normally occurs with the noun 'moon'. The chance for a direct translation of the anthropomorphic reference is missed. The expansion of the noun phrase 'calm splendour of the moon', not supported by linguistic material in the ST, creates a syntactic parallelism with the 'flickering flame of the oil lamp', which heightens the style of the TT and therefore mirrors the translator's interference with the ST. Steegman's lexical choice, however, is interesting. The premodifier 'calm', in fact, refers to 'the mind, feelings, or demeanor' ('calm' in OED (Note 2)), and it can also be used in collocates with sea, water and air (British National Corpus (Note 3)). While omitting the anthropomorphic reference, Steegman appears to be opting for a 
compensating strategy more suited to her interpretation of the possible level of 'humanization' in nature. The anthropomorphic reference and the 'active' representation of nature have been erased. A compensating strategy employing a different metaphorical expression tries to reproduce the effect of the ST, but it is unclear whether it derives from different mapping conditions or Steegman's subjective preference.

(2)

ST Il chiarore ora azzurro ora giallo della luna travolta da grandi nuvole in corsa illuminava il prato erboso, la piazzetta sterrata davanti alla chiesa e alla parrocchia, e due fila di casupole serpeggianti ai due lati d'una strada in pendio che andava a perdersi fra le macchie della vallata. E in mezzo a questa appariva, come un'altra strada grigia e tortuosa, il fiume che a sua volta andava a confondersi tra i fiumi e le strade del paesaggio fantastico che le nuvole, spinte dal vento, componevano e scomponevano ogni tanto sull'orizzonte allo sbocco della valle (Deledda, 1920, pp. 6-7).

TT The uncertain light, now blue, now yellow, as the moon's face shone clear or was traversed by big clouds, illumined the long grass of the field, the little raised piazza in front of the church and presbytery, and the two lines of cottages on either side of the steep road, which wound on and downwards till it lost itself amidst the trees in the valley. And in the centre of the valley, like another grey and winding road, was the river that flowed on and in its turn lost itself amidst the rivers and roads of the fantastic landscape that the wind-driven clouds alternately revealed and concealed on that distant horizon that lay beyond the valley's edge (Deledda, 1923, p. 7).

In the ST, the past participle 'travolta' (overwhelmed) suggests that the moon is once more interpreted in human terms, and so are the clouds ('in corsa', running). These choices evoke an image of liveliness and movement. In the TT, 'traversed' (travelled across or through) is weaker than 'travolta', and the idea of speed conveyed by 'in corsa' is completely omitted. In the same sentence, the added adjunct 'as the moon's face shone clear', not supported by ST material, makes the entailment of the TT image more explicit. At the end of the first sentence, the noun phrase 'una strada che andava a perdersi' was preserved in the TT with the use of the verb phrase 'lost'.

This excerpt also features examples of transposition/recategorization. The metaphorical use of 'serpeggiante' for the 'casupole', which indicates a horizontal movement from left to right, is no longer present. The adjective chosen to describe the 'casupole' in the ST is recategorized and turned into a relative clause describing the road in the TT ('which wound on and downwards'). The metaphorical motion is preserved but domesticated, for the coupling of road with motion, in fact, is not new (Kövecses, 2014, p. 25).

The clouds performing a human action are the main protagonists of the anthropomorphic reference in the second sentence of the ST excerpt, where 'componevano e scomponevano' conjures up the active image of 'putting together'. In the TT, the lexical shift in 'reveal' rather reminds of mystery. This choice, however, is not based, like the previous ones, on frequent collocates. In the 1920s only five occurrences of the verb 'conceal' could be found together with 'clouds' (Note 4), all of them coming from Wordsworth's poetry. In the previous and following decades (1890-1900-1930) the collocation 'cloud + conceal' was still rare, and once more attributable to Wordsworth. If Steegman was aware of this use, she could have tried to insert an intertextual domesticating reference.

ST Nel paesetto già più non si vedeva un lume, un filo di fumo. Dormivano, le povere casette arrampicate come due file di pecore su per la china erbosa, all'ombra della chiesetta che col suo esile campanile, riparato a sua volta sotto il ciglione, pareva il pastore appoggiato al suo vincastro (Deledda, 1920, p. 7).

TT In the village itself not a light was to be seen, nor even a thread of smoke. They were all asleep by now in the poverty-stricken cottages, which clung to the grassy hill-side like two rows of sheep, whilst the church with its slender tower, itself protected by the ridge of land behind it, might well represent the shepherd leaning upon his staff (Deledda, 1923, p. 7).

The houses in the ST are anthropomorphized as living beings now asleep. The TT omits the metaphor, and the noun phrase 'the houses', turned into an adjunct, loses prominence. While the simile 'come due file di pecore' / 'like two rows of sheep' is preserved, it is worth noticing that the shift from 'arrampicare' (Note 5) (directly translatable as 'to climb': 'to raise oneself by grasping or clinging, or by the aid of hands and feet' (Note 6), which implies height), to 'cling' ('to adhere together in a stiff or firm mass' (Note 7)) describes a different action and favours a mental representation of a less steep landscape in the target readers' minds. 
ST Il vento gli rubava le parole di bocca e le sperdeva lontano (Deledda, 1920, p. 16).

TT But his words were lost in the shrill whistling of the wind (Deledda, 1923, p. 24).

In the ST, the wind bears unmistakably human traces in performing the action of 'stealing'. The agentivity of the wind is not acknowledged and consequently not reproduced in the TT, where the wind loses prominence and becomes an adjunct. This is further reinforced by the shift from active to passive voice. Steegman preserved the expected collocate with wind (whistle (Note 8)) but the addition of shrill, however literary in tone and usually found with 'wind' (Note 9), manages to evoke human features.

(5)

ST: Il vento fuori strisciava più intenso [...] (Deledda, 1920, p. 12).

TT: Outside the wind moaned and whistled more loudly still [...] (Deledda, 1923, p. 12).

In the ST, the verb 'strisciare' describes the movement of the wind contextualized in a more menacing atmosphere (reinforced by a later reference to the devil). In the TT, Steegman chooses verbs which occur normally with 'wind'. Unlike example 1, in which the noun phrase 'calm splendour' was meant to provide an anthropomorphic interpretation, no compensation strategy was introduced here. Furthermore, amplification is detectable in the verbs 'moan and whistle', none of which expresses the conceptual framework of the ST.

ST Page Si era anche allora di primavera, ma tutta la vallata sembrava d'un tratto ripresa dall'angoscia invernale; ogni foglia si torceva, gli alberi si piegavano e pareva guardassero di qua e di là spauriti le nuvole che salivano rapide nere e lucenti da tutte le parti dell'orizzonte e andavano le une contro le altre, come eserciti in battaglia; grossi chicchi di grandine cadevano come palle bucando le foglie tenere (Deledda, 1920, pp. 15-16).

TT It had been springtime then, too, but the whole valley seemed to have slipped back into the grip of winter. Leaves were blown hither and thither, the trees bent before the blast, leaning one against another, as though gazing fearfully at the battalions of black clouds driving rapidly across the sky from all parts of the horizon, while large hailstones fell and bruised the tender green (Deledda, 1923, p. 24).

This excerpt exemplifies Deledda's use of pathetic fallacy as a means to humanize nature. Since nature assumes human emotional attributes, in the ST the empathy between man and nature is at its peak: the Sardinian valley experiences 'angoscia' (anguish), whereas the TT features 'grip', a frequent collocate of winter. Moreover, in the ST there is a vivid image of pain in the reflexive verb 'torcersi' (writhe) not present in the TT, where the passive voice "were blown" deprives the leaves of their agentivity. However, the meaning of the adjective 'spauriti', which usually describes helpless children, was preserved via recategorization (the adverb 'fearfully'). Pathetic fallacy is particularly recurrent in the Psalms (Porteous, 1986, p. 6), thus potentially meaningful in a novel so deeply entwined with religious contents like La Madre. The scant research on Deledda's use of metaphor, however, does not allow to trace a definite connection.

In the example, the sky is conceptually visualized as a battlefield by the 'battalions' of black clouds. The simile in the ST becomes a metaphor in the TT, some elements are recategorized ('nuvole' becomes a postmodifier) and other are omitted ('andavano le une contro le altre' - 'one against the other'). Compensation in terms of anthropomorphism can be found in the addition of one metaphor: the leaves (described through a metonymy, 'the tender green') are 'bruised' because they are as fragile and delicate as human skin.

The analysis revealed that the preponderance of the conceptual metaphor LANDSCAPE AS A PERSON in La madre corresponds to Deledda's deep connection to the Sardinian landscape. Deledda exploits anthropomorphism to emphasize the characters' subjective experience, which aligns with Gibbs's "vividness hypothesis" (1994, p. 125). The image of a dynamic landscape is further reinforced by the anthropomorphic references realized by active verbs ('guardava'; 'componevano e scomponevano'; 'dormivano'; 'rubava'; 'strisciava'; 'ripresa dall'angoscia'; 'torceva'). The anthropomorphic descriptions play an important role in the narrator's voice, defining the deep emotional connection with the Sardinian nature and, on a larger scale, contributing to the impression of a narrative universe shared by the narrator, the characters, and ultimately the reader. It can be therefore concluded that the metaphor LANDSCAPE AS A PERSON is a megametaphor which appears consistently throughout the novel. Conversely, the exclusion of many dynamic verbal collocations ('think', 'know', 'believe') referring to nature in The Mother confirms a disinclination for non-human agents (Fill, 2001, p. 48; Halliday, 2001, p. 194), thus weakening the impact of the anthropomorphic megametaphor in the TT. Nature is ultimately depicted as a mere narrative tool used to highlight the characters' psychological development. The narrator's 
experience is reshaped, leaving the target reader with a sense of distance and lack of emotional involvement, which influences their understanding of Deledda's poetics.

The diachronic impossibility of an empirical, process-oriented analysis (Schäffner, 2017, p. 257) only allows for hypotheses on Steegman's approach. Firstly, the avoidance of conflict caused by the reduction of anthropomorphic references is consistent with the translation of other landscape-related metaphors (Fois, 2020c). Secondly, the reduction of anthropomorphic references and pathetic fallacies could be linked to Steegman's subjective interpretation. Anthropomorphism and pathetic fallacy, in fact, are generally less acceptable for those who perceive the individual as autonomous and separate from the outside world (Kaboré, 2016, p. 157). Such a hypothesis, however, would necessitate a more thorough examination of all of Steegman's translations in order to determine the recurring presence of this strategy in the treatment of metaphors.

\section{Conclusions}

Anthropomorphic metaphors, with their unambiguous meaning, should pose no translation problem in terms of comprehension. Furthermore, according to Prandi's theoretical framework, the conflict and incoherence embedded in these particular types of living metaphor are shared by the English and the Italian culture, removing the cognitive obstacles to a direct translation of the anthropomorphic references. The Mother confirms that the translating choices concerning metaphor are not solely influenced by corresponding of diverging conceptual domains (Schäffner, 2017, p. 258).

In La madre, the Sardinian landscape is described as a living and active agent rather than a passive background. The anthropomorphic references, however, are greatly reduced in the TT. The deeper level, in which nature becomes a character in its own right and is inextricably linked to the narrator (and also the author), fails to be conveyed. The narrator of Steegman's translation acts as a facilitator for the target reader, while Deledda's narrator is emotionally invested. The conceptualization thet the ST narrator uses to see the world and create reality (Feder Kittay, 1987, p. 17) is missing. Steegman's omission of anthropomorphism is consistent with her translation's overall domesticating choices (Fois, 2020a). She may have attempted to delete all conflictual and incoherent contents that could pose a challenge to the reader's reception or a disruption to her personal ideology: as figurative language is said to stem from irrational passion, anthropomorphism and rationality are not compatible (Regier, 2006, p. 422) and this could be one of the possible explanations for Steegman's omission.

Translation of metaphor does influence the way the narrative world is presented to and thus understood by the reader (Dorst, 2019). Landscape and nature are among the variables that reveal different cultural frameworks and affect the identity of the TT. Deledda's metaphorical use of the Sardinian landscape proved to be more difficult to grasp, understand, and reinterpret by a translator from a different cultural dimension and a privileged position, who was probably less inclined to make such an effort.

\section{References}

Airenti, G. (2019). The development of anthropomorphism in interaction: Intersubjectivity, imagination, and theory of mind. In G. Airenti, M. Cruciani \& A. Plebe (Eds.), The Cognitive Underpinnings of Anthropomorphism (pp. 5-6). Frontiers. https://doi.org/10.3389/978-2-88963-038-7

Atkins, P. (1998). Metaphors and Meanings in Modern Landscapes: Reading the Landscape. In P. Atkins, I. Simmons \& B. Roberts (Eds.), People, Land and Time (pp. 219-230). London: Hodder Arnold.

Baer, B. J. (2016). Translation Criticism in Newspaper Reviews. In M. Woods (Ed.), Authorizing Translation (pp. 12-31). London: Routledge.

Bitti, S., Cherchi, T., Congiu, S., Fancello, A., Floris, G., Porcu, G., ... Scarteddu A. (1974). Costanti del mondo deleddiano. In Convegno nazionale di studi deleddiani: Nuoro, 30 settembre 1972, atti (pp. 191-209). Cagliari: Editrice sarda Fossataro.

Corrias, P. (2011). Il coraggio della dipendenza. Grazia Deledda, 'La Madre' (1920). In A. Ribero \& R. Luisa (Eds.), Il simbolico in gioco. letture situate di scrittrici del Novecento (pp. 15-52). Padova: Il Poligrafo.

Dancygier, B., \& Sweetser, E. (2014). Figurative Language. Cambridge: Cambridge University Press.

Danta, C. (2013). The New Solitude: Melancholy Anthropomorphism and the Molecular Gaze. English Studies in Canada, 39(1), 71-86. https://doi.org/10.1353/esc.2013.0017

De Bleeker, L. (2014). Translating space in narrative fiction: Patrick Chamoiseau's Martinique seen from a Dutch and English perspective. Language and Literature, 23(3), 227-243. https://doi.org/10.1177/0963947014536502 
De Giovanni, N. (2017). Vento di Terra, Vento di mare: Grazia Deledda oltre l'isola. Alghero: Edizioni Nemapress.

Deledda, G. (1901). Tipi e paesaggi sardi. Nuova Antologia, 96(4), 593-623.

Deledda, G. (1920). Milano: Fratelli Treves Editore.

Deledda, G. (1923). The Mother (Mary G. Steegmann, Trans.). New York: The MacMillan Company.

Deledda, G. (1938). Versi e prose giovanili di Grazia Deledda. Milano, Treves.

Dorst, A. G. (2019). Translating metaphorical mind style: machinery and ice metaphors in Ken Kesey's One Flew over the Cuckoo's Nest. Perspectives, 27(6), 875-889. https://doi.org/10.1080/0907676X.2018.1556707

Douthwaite, J., Virdis, D. F., \& Zurru, E. (Eds.) (2017). The stylistics of landscapes, the landscapes of stylistics. Amsterdam: John Benjamins Publishing Company. https://doi.org/10.1075/lal.28

Eggan, T. A. (2018). Landscape Metaphysics: Narrative Architecture and the Focalisation of the Environment. English Studies, 99(4), 398-411. https://doi.org/10.1080/0013838X.2018.1475594

Epley, N., Waytz, A., \& Cacioppo, J. T. (2007). On Seeing Human: A Three-Factor Theory of Anthropomorphism. Psychological Review, 114(4), 864-886. https://doi.org/10.1037/0033-295X.114.4.864

Feder Kittay, E. (1987). Metaphor: Its Cognitive Force and Linguistic Structure. Hong Kong: Oxford University Press.

Fois, E. (2014). Il traduttore c'è e talvolta si vede: il caso Prunas Tola. Letterature Straniere, 15, 125-140.

Fois, E. (2020a). Translating Foreign Space and Landscape: The Mother by Grazia Deledda. Verbis Lingue Letterature Culture, 10(2), 137-160.

Fois, E. (2020b). The English Translation of Grazia Deledda's La Madre and the Relevance of Culture in Translating Landscape Metaphor. Cadernos de Tradução, 40(2), 112-130. https://doi.org/10.5007/2175-7968.2020v40n2p112

Fois, E. (2020c). The Rendition of Metaphors and the Translator's Influence in the English Translation of Grazia Deledda's La Madre. Palimpsest, 5(9), 53-66, https://doi.org/10.46763/PALIM2090053f

Fuller, P. J. (2000). Regional Identity in Sardinian Writing of the Twentieth Century: The World of Grazia Deledda and Giuseppe Dessì. Italianist, 20(1), 58-97. https://doi.org/10.1179/ita.2000.20.1.58

Gavins, J., \& Lahey, E. (2016). World Building in Discourse. In J. Gavins \& E. Lahey (Eds.), World Building: Discourse in the Mind (pp. 1-13). London: Bloomsbury Publishing Plc.

GDLI Grande dizionario della lingua italiana, Utet grandi opere, http://www.gdli.it/

Gibbs, R. (1994). The poetics of mind. Cambridge, UK: Cambridge University Press.

Goatly, A. (1997). The language of metaphors. London: Routledge. https://doi.org/10.4324/9780203210000

Goodman, N. (1968). Languages of Art. Indianapolis: Bobbs-Merrill.

Grabe, I. (1984). Local and Global Aspects of Interaction Processes in Poetic Metaphor. Poetics, 13, 433-457. https://doi.org/10.1016/0304-422X(84)90017-2

Gray, K., \& Wegner, D. M. (2009). Moral typecasting: Divergent perceptions of moral agents and moral patients. Journal of Personality and Social Psychology, 96(3), 505-520. https://doi.org/10.1037/a0013748

Grech, M. (2018). 'Where Nothing Ever Was': Anthropomorphic Spectrality and the (Im)possibility of the Post-Anthropocene. New Formations, 95, 22-36. https://doi.org/10.3898/NewF:95.02.2018

Guarnieri, A. (2008). La forza delle passioni e la vanità del sacrificio. note di lettura su La madre di Grazia Deledda. Letteratura \& Società, 2, 58-78.

Halliday, M. A. K. (2001). New Ways of Meaning: The Challenge to Applied Linguistics. In A. Fill \& P. Mühlhäusler (Eds.), The Ecolinguistic reader (pp. 175-202). London-New York: Continuum.

Hough, C. (2016). The metaphorical landscape. In W. Anderson, E. Bramwell \& C. Hough (Eds.), Mapping English Metaphor Through Time (pp. 13-31). Oxford: Oxford University Press. https://doi.org/10.1093/acprof:oso/9780198744573.003.0002

Johnson, J. H. (2009). Towards an Identification of the Authorial Style of Grazia Deledda. A Corpus-Assisted Study. In D. R. Miller (Ed.), Occasional papers (p. 24). Bologna: Centro di Studi Linguistico-Culturali 
(CeSLiC).

Kaboré, A. (2016). Theorizing Ecclesial Ecocriticism: Pathetic Fallacy in Ecclesiastical Literature on Climate Change. Environment and Ecology Research, 4(3), 155-160. https://doi.org/10.13189/eer.2016.040307

Kövecses, Z. (2014). Conceptual Metaphor theory and the nature of difficulties in metaphor translation. In D. R. Miller \& E. Monti (Eds.), Translating figurative language (pp. 25-39). Bologna: CeSLiC.

Kruger, A. (1991). Translating metaphors that function as characterisation technique in narrative fiction. Journal of Literary Studies, 7(3/4), 289-298. https://doi.org/10.1080/02564719108529991

Lahey, E. (2010). Megametaphorical mappings and the Landscapes in Canadian Poetry. In M. Lambrou \& P. Stockwell (Eds.), Contemporary Stylistics (pp. 156-167). London: Continuum.

Lakoff, G., \& Johnson, M. (1980). Metaphors We Live By. Chicago: University of Chicago Press.

Magistro, E. (2007). Forging an Art: The Early Novels of Grazia Deledda. In S. Wood (Ed.), The Challenge of The Modern: Essays on Grazia Deledda (pp. 57-85). Leicester: Troubador.

Mandelblit, N. (1995). The cognitive view of metaphor and its implications for translation theory. In Translation and Meaning (Part 3). Maastricht: Universitaire Press.

Markowsky, J. K. (1975). Why anthropomorphism in children's literature? Elementary English, 52(4), 460-466.

Massaiu, M. (1976). La Sardegna di Grazia Deledda. Cagliari: Editrice sarda Fossataro.

Miccinesi, M. (1975). Grazia Deledda. Milano: la Nuova Italia.

Migiel, M. (1994). Grazia Deledda (1871-1936). In R. Russell (Ed.), Italian Women Writers: A Bio-bibliographical Sourcebook (pp. 111-118). Ed. Greenwood Press.

Muelder Eaton, M. (1990). Responding to the Call for New Landscape Metaphors. Landscape Journal, 9(1), 22-27. https://doi.org/10.3368/lj.9.1.22

Newmark, P. (1981). Approaches to Translation (Language Teaching Methodology Senes). Oxford: Pergamon Press.

Oxford English Dictionary. (2021). Discover the story of English. Oxford University Press. Retrieved from https://www.oed.com/

Porteous, D. J. (1986). Body scape: The Body-Landscape Metaphor. The Canadian Geographer, 30(1), 2-12. https://doi.org/10.1111/j.1541-0064.1986.tb01020.x

Prandi, M. (2010). Typology of Metaphors: Implications for Translation. Mutatis Mutandis, 3(2), 304-332.

Prandi, M. (2015). Translating metaphors. In E. Miola \& P. Ramat (Eds.), Language across Languages (pp. 83-104). Newcastle upon Tyne: Cambridge Scholars Publishing.

Prandi, M. (2017). Conceptual conflicts in metaphor and figurative language. New York: Routledge. https://doi.org/10.4324/9781315208763

Prandi, M. (2019). Une typologie des metaphores en vue de la traduction. In R. Trim \& D. Śliwa (Eds.), Metaphor and Translation (pp. 24-39). Newcastle upon Tyne: Cambridge Scholars Publishing.

Regier, A. (2006). Figuring it out: The Origin of Language and Anthropomorphism. Forum for Modern Language Studies, 42(4), 412-430. https://doi.org/10.1093/fmls/cq1073

Rezanova, Z., \& Konstantin, S. (2015). Megametaphor as a coherence and cohesion device in a cycle of literary texts. Lingua Posnaniensis, 57(2), 31-39. https://doi.org/10.1515/linpo-2015-0009

Ruschioni, A. (1974). Poesia delle cose e poetica della luce in Grazia. Deledda. In R. Ruju (Ed.), Convegno Nazionale di studi deleddiani, Nuoro, 30 settembre 1972 (pp. 433-477). Cagliari: Fossataro.

Schäffner, C. (2004). Metaphor and translation: Some implications of a cognitive approach. Journal of Pragmatics, 36, 1253-1269. https://doi.org/10.1016/j.pragma.2003.10.012

Schäffner, C. (2017). Metaphor in Translation. In E. Semino \& Z. Demjén (Eds.), The Routledge Handbook of Metaphor and Language (pp. 247-262). Abingdon: Routledge.

Semino, E., \& Steen, G. (2008). Metaphor in literature. In R. W. Gibbs Jr. (Ed.), The Cambridge handbook of metaphor and thought (pp. 232-246). Cambridge: Cambridge University Press. https://doi.org/10.1017/CBO9780511816802.015

Steen, G. (2014). Translating metaphors: what's the problem? In D. R. Miller \& E. Monti (Eds.), Translating 
figurative language (pp. 11-24). Bologna: CeSLiC.

Steinhagen, C. (1999). Dangerous Crossings: Historical Dimensions of Landscape in Willa Cather's My Ántonia, The Professor's House, and Death Comes for the Archbishop. Interdisciplinary Studies in Literature and Environment, 6(2), 63-82. https://doi.org/10.1093/isle/6.2.63

Sulis, G. (2017). Sardinian Fiction at End of the Twentieth and Beginning of the Twenty-first Century: An overview and first assessment. Incontri, 32(2), 69-79. https://doi.org/10.18352/incontri.10219

Unwin, S. (2019). Metaphor: An Exploration of the Metaphorical Dimensions and Potential of Architecture. London: Routledge. https://doi.org/10.4324/9781315171906

Werth, P. (1999). Text Worlds: Representing Conceptual Space in Discourse. Pearson Education Inc.

Westh, P. (2009). Anthropomorphism in God concepts: The role of narrative. In A. W. Geertz (Ed.), Origins of Religion, Cognition and Culture (pp. 396-413). Equinox Publishing.

Williams, M. O., Whitmarsh, L., \& Mac, G. C. D. (2021). The association between anthropomorphism of nature and pro-environmental variables: A systematic review. Biological Conservation, 255 https://doi.org/10.1016/j.biocon.2021.109022

Zerkowitz, J. (2017). 'How Others See ...': Landscape and identity in a translated poem by Radnóti. In J. Douthwaite, D. F. Virdis \& E. Zurru (Eds.), The Stylistics of Landscapes, the Landscapes of Stylistics (pp. 81-93). Amsterdam: John Benjamins Publishing Company. https://doi.org/10.1075/lal.28.06zer

\section{Notes}

Note 1. The Mother in Steegman's translation was also included in Giosè [sic] Carducci, Grazia Deledda, José Echegaray, T.S Eliot, a collection of novels by various Italian authors published by Alex Gregory (New York) in 1971.

$\begin{array}{llllll}\text { Note } & 2 . & \text { Retrieved } & \text { July } & 19, & \text { 2021, }\end{array}$ https://www.oed.com/view/Entry/26481?rskey=uo1 gbm\&result=1\&isAdvanced=false\#eid

Note 3. Also in OED: (literal) of the weather, air, or sea: opposed to storm. Retrieved from https://www.english-corpora.org/bnc/

Note 4. Retrieved from https://googlebooks.byu.edu/x.asp

Note 5. 'arrampicarsi' in Treccani: 'salire aggrappandosi, detto di persone o d'animali, e per estens. di piante o altro. Retrieved February 4, 2020, from http://www.treccani.it/vocabolario/arrampicarsi/

Note 6. 'Climb' in OED: 'To raise oneself by grasping or clinging, or by the aid of hands and feet'. Retrieved July 19, 2021, from https://www.oed.com/view/Entry/34342?rskey=iKef5o\&result=2\&isAdvanced=false\#eid

Note 7. 'Cling' in OED. Retrieved July 19, 2021, from $<$ https://www.oed.com/view/Entry/34369?rskey=jRFBL1\&result=3\&isAdvanced=false\#eid

Note 8. 'whistle' in OED: 'To produce a shrill sound of this kind in any way, esp. by rapid movement, as the wind, a missile, the lash of a whip'. Retrieved July 19, 2021, from https://www.oed.com/view/Entry/228547?rskey=F49DCX\&result=2\&isAdvanced=false\#eid

Note 9. 'shrill' in OED: 'Of voice, sound: Of a sharp high-pitched piercing tone'. Retrieved July 19, 2021, from https://www.oed.com/view/Entry/178871?rskey=wwTQHp\&result=2\&isAdvanced=false\#eid

\section{Copyrights}

Copyright for this article is retained by the author, with first publication rights granted to the journal.

This is an open-access article distributed under the terms and conditions of the Creative Commons Attribution license (http://creativecommons.org/licenses/by/4.0/). 